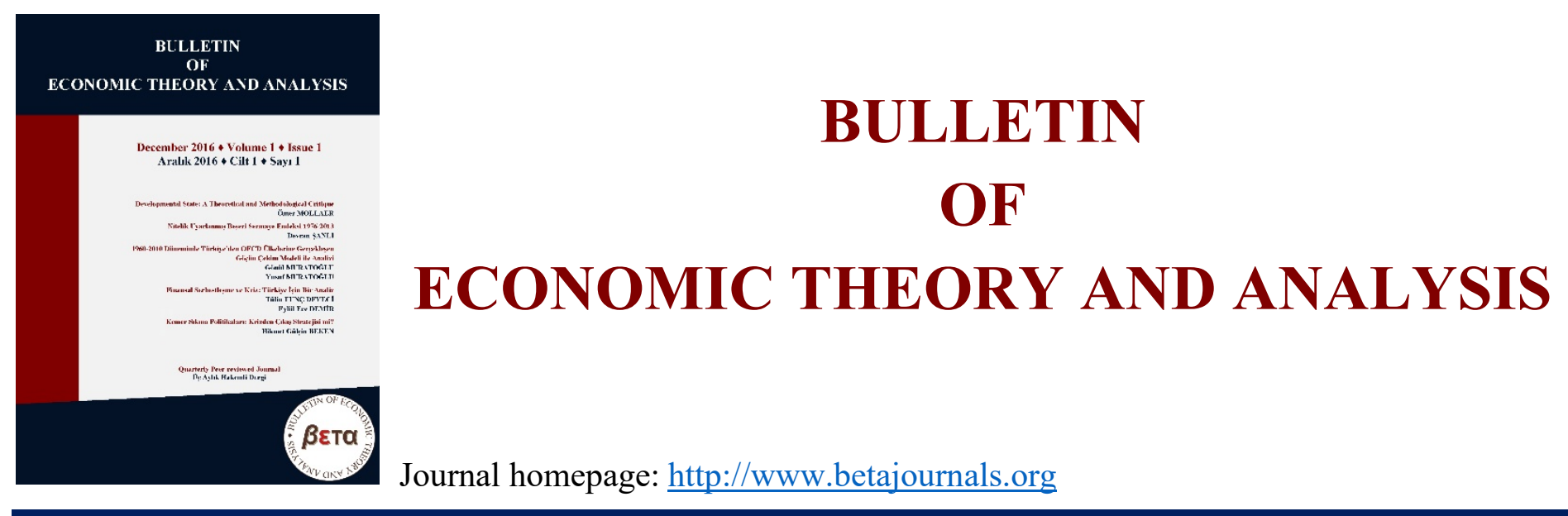

\title{
The Effects of Financial Development on Trade Openness: Evidence from Panel Threshold Regression Models
}

\section{Zühal KURUL @ $\mathrm{https://orcid.org/0000-0001-9677-8260}$}

To cite this article: Kurul, Z., (2021). The Effects of Financial Development on Trade Openness: Evidence from Panel Threshold Regression Models. Bulletin of Economic Theory and Analysis, 6(1), 53-68.

Received: 28 Feb 2021

Accepted: 21 May 2021

Published online: 30 Jun 2021

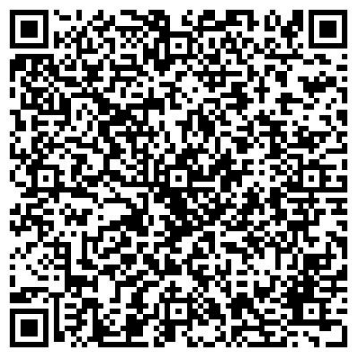




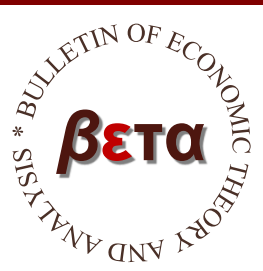

\title{
Bulletin of Economic Theory and Analysis
}

Volume VI, Issue 1, pp. 53-68, 2021

http://www.betajournals.org

Original Article / Araştırma Makalesi

Received / Alınma: 28.02.2021 Accepted / Kabul: 21.05.2021

\section{The Effects of Financial Development on Trade Openness: Evidence from Panel Threshold Regression Models}

\author{
Zühal KURUL ${ }^{\mathrm{a}}$
}

a Assist.. Prof. Dr., Hacettepe University, FEAS, Department of Econometrics, Ankara, TURKEY

(C) https://orcid.org/0000-0001-9677-8260

\begin{abstract}
This paper attempts to re-examine the finance-trade nexus and tests whether higher levels of financial development can reduce trade openness. Using static and dynamic panel threshold regression techniques based on 64 countries over the period of 1970 2014, this study shows that financial development fosters trade openness until a certain level of threshold is achieved and beyond that threshold level, further increases in financial development lead to decline in trade openness. The results of this study suggest that there is a need for developing alternative and new trade financing channels to increase trade openness as well as it provides a strong empirical support for tradelimiting effects of financial development. Hence, this study is possibly encouraging for policy makers to redesign trade enhancing policies.
\end{abstract}

Keywords

Financial

Development, Trade

Openness, Panel

Threshold

Regression Models

JEL Classification

E44, F14, C23

CONTACT Zühal KURUL $₫$ zkurul@hacettepe.edu.tr $\risingdotseq$ Hacettepe University, FEAS, Department of Econometrics, Ankara, TURKEY 


\section{Finansal Gelişmişliğin Ticari Açıklık Üzerindeki Etkisi: Panel Eşik Değer Regresyon Modellerinden Kanitlar}

\begin{abstract}
ÖZ
$\mathrm{Bu}$ çalışmanın amacı finans-ticaret ilişkisini yeniden incelemek ve finansal gelişmişliğin ticari açıklık üzerinde azaltıcı etkilerinin olup olmadığını test etmektedir. Çalışmada 64 ülkeye ait 1970-2014 dönemini kapsayan verilerle ve statik ve dinamik panel eşik değer regresyon teknikleri kullanılarak elde edilen sonuçlara göre finansal gelişmişlik ticarete açıklığ 1 belirli bir eşik düzeye kadar artırmakta birlikte bu eşik değerin aşılmasıyla finansal gelişmiş̧likteki iyileşmeler ticari açıklığın düşmesine neden olmaktadır. Çalışmanın sonuçları finansal gelişmişliğin ticaret azaltıcı etkilerine yönelik olarak güçlü ampirik kanıtlar sunmakla birlikte ticari açıklığı artırıcı yeni ve alternatif yolların geliştirilmesi gerekliliğini ortaya koymaktadır. Dolayısıyla bu çalışma politika yapıcıların ticareti genişletmeye yönelik politikaları yeniden tasarlanması için teşvik edicidir.
\end{abstract}

\author{
Anahtar Kelimeler \\ Finansal \\ Gelişmişlik, \\ Ticarete Açıklık, \\ Panel Eşik Değer \\ Regresyon \\ Modelleri \\ JEL Kodu \\ E44, F14, C23
}

\section{Introduction}

In recent years, there has been a growing amount of research concerning the effects of financial development on trade openness. The existing evidence mostly suggest a positive linear relationship between financial development and trade openness. However, this widespread consideration in finance-trade nexus seems to be more complex for several reasons. First, it is intuitively recognized that exporting and importing firms tend to benefit from increasing level of credit availability in well-functioning financial systems, but it does not guarantee the high accessibility to better trade financing opportunities and hence the higher levels of trade openness. Second, in both developed and developing countries, due to the rapid rise in financial sector since 1990s, financial sector has become a competing sector with other sectors, especially with productive trade-intensive sectors. The rise of finance thus leads to transfer of more resources (e.g. high-skilled labour) from trade-intensive sectors to financial sector and causes decline in trade. Third, although larger financial systems increase availability of credit facilities, the allocation may be problematic for trade intensive sectors. In other words, if a larger financial sector provides more credit to non-tradable sectors, exporting and importing firms might experience difficulties.

This study is also related with ongoing developments in global trade. In recent years, there has been a remarkable slowdown in volume of trade, especially when it is compared with its sound 
historical performance. Aftermath of the weak recovery from 2008 Global Financial Crisis, the percentage level of world trade in GDP is recorded as 56.02 in 2016, below the pre-crisis levels. As argued in Aslam, Boz, Cerutti, Poplawski-Ribariro \& Topalova (2018), there has been a considerable deceleration in global trade since 2012. For instance, world exports and imports have grown annually by just 2-3 percent suggesting a trade slowdown period between 2010-2016 (World Development Indicators, 2016). In the light of complex nature of finance-trade nexus and the recent developments in global trade, providing a more precise understanding on these issues has become substantially important for implementing trade promoting policies in future. Therefore, throughout this paper, I attempt to re-examine the effects of financial development on trade openness by considering the possible nonlinearities and trade-limiting outcomes.

In the neoclassical trade theory, it is emphasized that differences across countries in their factor endowments and technology or scale economies are likely to be sources of comparative advantage (Alam, Selvanathan \& Hossain, 2019). However, various theoretical approaches have been put forward to provide an explanation for the finance-trade nexus over the past three decades. For instance, Kletzer and Bardhan (1987), first systematically demonstrate the importance of financial sector and note that financial sector is a kind of factor endowment. Their argument implies that the source of comparative advantages can also be based on differences in financial sector developments. In their augmented Heckscher-Ohlin (H-O) model, the differences between countries in their quality of contact enforcement and risk diversification are the main factors and these factors determine the international specialization. Therefore, Kletzer and Bardhan (1987)'s prediction is that the countries with high quality financial sectors specialize in the production of goods that are more dependent to financial sector. In this framework, more well-functioning financial sectors contribute to trade financing and drive trade performance. Recently, theoretical literature has grown with new models that show the significant role of financial development in determining pattern of trade. Several studies (Beck, 2002; Matsuyama, 2005 and Wynne, 2005) emphasize the importance of external finance and report that the countries with more developed financial systems are comparatively advantageous in industries intensively use external finance. More recently, Jun and Wei (2008) integrate institutional quality factors into a general equilibrium model and insert financial sector development into institutions. They distinctly report that while in countries with high quality institutions further improvements in institutional quality are not influential on both output and trade patterns, in countries with low quality institutions, institutional 
quality becomes the main determinant of output and trade patterns.

Empirically Beck (2003), Svaleryd \& Vlachos (2005), Hur, Raj \& Riyanto (2006), Manova (2008) and Manova et al. (2009) affirm that financially developed countries have higher export shares in industries that are in need of more external finance and increase their export shares at higher levels of financial development. Becker et al. (2012) draw our attention to interactions between financial development, fixed costs and trade and state that financial development positively affects exports in high fixed cost industries. Furthermore, Berthou (2007) specifically examines the impact of credit constraints on the observed zero trade flows over time and find that higher levels of financial development lead to an increase in the probability that two countries are trade partners and also in export volumes between countries. Most of the recent studies summarized above reach the conclusion that there is a positive effect of financial development on trade. Nevertheless, the relation between financial sector development and trade can change when further discussions are considered. For example, as in the finance-growth relationship, a nonlinear link can be reflected in the finance-trade relationship. Countries may enjoy financial deepening due to opening up international trade and providing comparative advantage. However, with the increase in financial size, the benefits of financial development on trade openness may vanish after a certain level is achieved.

There exists a number of channels through which financial development is nonlinearly affects trade. One explanation can be provided by reviewing the theoretical considerations of Tobin (1984) about the efficiency of financial systems. In this explanation, a growing financial sector may cause a "suboptimal allocation of talents" as argued in Arcand, Berkes and Panizza (2015) in the form of attracting high skilled workers suggesting that the competition arises between financial sector and productive trade intensive sectors. Furthermore, the expansion of financial sector may direct bank credits to excessive household lending which is a non-tradable sector. Unless lending is used to finance the investments of productive firms in export sectors, the impact of expansion of financial sector will likely be insignificant on trade openness. Similarly, if financial innovations lead to decline in savings, the accumulation of capital in real sector and subsequently the levels of output may decrease and therefore export capacities in those sectors may suffer (Beck, Degryse \& Kneer., 2014; Arcand et al., 2015; Gächter \& Gkrintzalis, 2017). Therefore, increases in financial size can negatively affect trade openness when a certain level is attained. 
The potential nonlinearity in the finance-trade literature with macro level data is first examined by Gächter and Gkrintzalis (2017) after recent contributions in finance-growth literature $^{12}$. Gächter and Gkrintzalis (2017) focus on the link between financial sector and trade and estimate a panel data model that includes an exogenous threshold variable represented by a dummy variable that interacts with financial development. ${ }^{3}$ Gächter and Gkrintzalis (2017) find that although financial development has a positive impact on trade openness, further increases in size of financial sector do not support trade when exogenously determined threshold is exceeded. More recently, Sare (2019) investigates the impacts of financial development on international trade for soma African countries by performing Hansen (2000)'s sample splitting approach that is designed for time series. Sare (2019) finds that the threshold impact of financial development on trade is country-specific.

In summary, the limitations of previous studies that try to test nonlinearities are the inclusion of exogenously determined thresholds and lack of a dynamic model that clearly defines and proposes endogenous thresholds for panel data. In this context, there is still need for reconsidering the impacts of financial development on trade openness by employing more recent and extended methods because this issue has several implications ranging from global trade trends to the domestic policy responses of countries.

This study contributes to the literature by using an empirical design that considers the factors that are overlooked in previous studies. First, the empirical analysis identifies the financial development thresholds endogenously and therefore moves beyond the earlier studies that point to nonlinearities with exogenous thresholds. Second, our study investigates the dynamic nature of trade openness by applying dynamic panel threshold regression model. This approach enables to capture more confident information on the true nature of the finance-trade nexus and paves the way of more reliable levels of thresholds.

In this paper, the trade-finance nexus is revisited by using a panel with 5-year averages of 64 countries over the period of 1970-2014 and it is found that higher level of financial development

\footnotetext{
2 Berthou (2007) and Manova (2015) also estimate nonlinear models with industrial and sectoral data.

${ }^{3}$ Gächter and Gkrintzalis (2017) estimate a benchmark model that includes squared terms of finance variables to show nonlinearity in a functional form. In order to find a threshold, they take the first derivative of the equation with respect to finance and set the derivative to zero. Then, they find the maximum which corresponds to the threshold.
} 
is associated with less trade openness when a certain level of threshold is achieved. The results suggest an inverted U-shape link between financial development and trade openness.

The rest of the study is organized as follows. Section 2 describes the empirical methodology, Section 3 introduces the data, Section 4 presents the empirical results and final section concludes and discusses some of the policy implications.

\section{Empirical Methodology}

Most of the studies in previous research assumes a priori functional form of the link between finance and trade and they rely on a framework that assumes a monotonic relationship. In spite of generally accepted results of previous literature, neglecting the potential nonlinearities may lead to misleading interpretations about the nature of the interaction between financial development and trade. Arcand et al. (2015) and Giorgioni (2017) argue that models that ignore non-monotonicity will lead to a downward bias in the estimation. To avoid misleading results, a panel data model designed for capturing the marginal effect of a variable at different stages of a threshold variable is employed. Apart from not imposing an exogenous threshold, an approach allowing for endogenously determined thresholds is followed. In this approach, endogenously determined thresholds help to split all observations into lower and upper regimes.

Since it suits for the compatibility and robustness purposes, two different panel threshold models are applied in this study: threshold model of Hansen (1999) that is designed for static panels and Kremer et al. (2013)'s framework for dynamic panels that considers the dynamic nature of the data.

\subsection{Static Panel Threshold Regression Model}

The empirical analysis first adopts a threshold regression model for static panels that is introduced by Hansen (1999). This model allows for determining an endogenous threshold level instead of imposing exogenous level of threshold that splits the overall regression. Thus, it can simultaneously estimate the level of threshold and obtain coefficients of variables above and below the estimated threshold. Hansen (1999)'s static panel threshold regression model can be represented as follows:

$$
Y_{i t}=\mu_{i}+\alpha^{\prime} X_{i t}+\beta_{1}^{\prime} Z_{i t} I\left(Z_{i t} \leq \lambda\right)+\beta_{2}^{\prime} Z_{i t} I\left(Z_{i t}>\lambda\right)+\varepsilon_{i t} .
$$

where subscripts $\mathrm{i}=1, \ldots, \mathrm{N}$ represents the country and $\mathrm{t}=1, \ldots, \mathrm{T}$ the time. $\mu_{i}$ is the country 
specific fixed effect. $Y_{i t}$ denotes the dependent variable. $Z_{i t}$ is the main explanatory variable and its impact is allowed to differ between regimes. In this specification, regimes are determined by an indicator function (I). This function helps to separate the overall regression into two regimes: upper regime and lower regime. Upper regime shows the relationship that is seen above the threshold level of $\lambda$ and lower regime represents the opposite. $X_{i t}$ is the vector of explanatory variables that are inserted as potential drivers of dependent variable and finally $\varepsilon_{i t}$ denotes the error term that allows for conditional heteroscedasticity and weak dependence.

In Hansen (1999)'s method, the individual effects $\left(\mu_{i}\right)$ are eliminated first by removing individualspecific means and then threshold is estimated through least squares estimation techniques. To evaluate the statistical significance of threshold effect, a bootstrap method is used. Finally, the slope coefficients of $Z_{i t}$ variable and other explanatory variables are estimated with least squares methods.

\subsection{Dynamic Panel Threshold Regression Model}

There is a more recent approach that is proposed by Kremer et al. (2013) to capture dynamic nature of the data. Kremer et al. (2013)'s approach is basically the extension of Caner and Hansen (2004)'s model that is designed for cross sectional data. To make their instrumental approach applicable to panel data specifications, Kremer et al. (2013) formulate a new method that involves the forward orthogonal deviations transformation that is put forward by Arellano and Bover (1995) and the basic instrumental variable techniques in Caner and Hansen (2004). Kremer et al. (2013)'s set up helps to remove country specific fixed effects by using an appropriate transformation formula and overcome possible endogeneity problems by allowing instrumenting by higher lags dependent variable. Thus, the basic formulation of a dynamic panel threshold regression can be written as follows:

$$
Y_{i t}=\mu_{i}+\gamma Y_{i, t-1}+\alpha^{\prime} X_{i t}+\beta_{1}^{\prime} Z_{i t} I\left(Z_{i t} \leq \lambda\right)+\beta_{2}^{\prime} Z_{i t} I\left(Z_{i t}>\lambda\right)+\varepsilon_{i t}
$$

Equation (2) includes a term $Y_{i, t-1}$ which is the lagged dependent variable. All the other components of Equation (2) are same with Equation (1). In this specification, country specific fixed effects $\mu_{i}$ are removed with forward orthogonal transformation method. ${ }^{4}$ Kremer et al. (2013) suggest that the best procedure for the estimation has three steps after forward orthogonal

\footnotetext{
${ }^{4}$ For details in orthogonal transformation see Kremer et al. (2013).
} 
transformation. First step is an instrumental variable estimation that is, regressing endogenous variable on selected instruments. The instruments in this step are higher lags of dependent variable. Second, it is appropriate to utilize the techniques of Hansen (1999) in order to determine the value of threshold. And finally, GMM procedures are applied to Equation (2) to estimate the coefficients of both the main variable that differs between two regimes and other explanatory variables.

\section{Data}

In this study, the static and dynamic panel threshold regression models are estimated by using three different trade openness indicators as dependent variables: trade to GDP ratio (TRADE/GDP), the exports to GDP ratio (EX/GDP) and finally the imports to GDP ratio (IM/GDP). Trade openness indicators represent exports and imports of goods and services in total. Although, the shares of manufacturing and service sector in trade may differ across countries and it is reasonable to distinguish these sectors, there are some difficulties in collecting data for service sector, we cannot distinguish service sector from the values of exports and imports. Financial development is the threshold variable and it is represented by Private Credit by Deposit Money Banks and Other Financial Institutions to GDP ratio (FINANCE). The financial development data is taken from Beck, Kunt \& Ross (2000) financial structure database. In all regression models, there are several control variables. For instance, GDP per capita (GDPPC) and gross fixed capital formation (GFC) reflect the development level and capital deepening of a country. Additionally, the ratio of general government final consumption expenditure to GDP (GOVCON) and inflation rate (INF) are used to explore the effects government policies in public finance and price distortions. All variables except from GDP per capita and inflation are expressed as percentages of GDP. Inflation represents the annual change in consumer price index and GDP per capita is calculated with constant 2010 US dollars. All data is transformed to a panel setting with 5-year averages over the period of 1970-2014 in order to avoid cyclical movements in variables. By doing so, our dataset becomes more appropriate to examine the long run impacts of finance on trade openness. Since our empirical methodology does not allow for working with unbalanced panels, we exclude some countries in our sample and hence we exercise our empirical analysis with 64 countries (developed and developing) due to data availability problems. 
Table 1

Descriptive Statistics

\begin{tabular}{lcccc}
\hline Variables & Mean & Std. Dev. & Min & Max \\
\hline Dependent Variable & & & & \\
TRADE/GDP & 71.025 & 52.070 & 8.663 & 410.864 \\
EX/GDP & 34.491 & 27.059 & 4.092 & 218.892 \\
IM/GDP & 36.533 & 25.711 & 4.516 & 191.972 \\
\hline Threshold Variable & & & & \\
FINANCE & 48.291 & 38.956 & 1.626 & 222.264 \\
\hline Control Variable & & & & \\
GDPPC & $14,103.231$ & $16,081.045$ & 225.757 & $89,835.203$ \\
GFC & 21.936 & 6.240 & 4.993 & 65.801 \\
GOVCON & 15.574 & 5.881 & -2.174 & 80.799 \\
INF & 27.706 & 152.190 & -1.173 & $2,414.346$ \\
\hline SOUF. Aun
\end{tabular}

Source. Author's calculations.

Table 1 presents the descriptive statistics of key variables. It is seen that all variables range widely across countries. More specifically, TRADE/GDP ranges widely across countries from 8.663 to 410.864, while EX/GDP ranges from 4.092 to 218.892 and IM/GDP varies between 4.516 and 191.972. The dependent variables have mean of $71.025,34.91$ and 36.533 with a standard deviation of 52.070, 27.059 and 25.711 respectively. The threshold variable FINANCE has a mean of 48.291 with standard deviation of 38.956 and ranges between 1.626 to 222.264. The selected control variables also have similar patterns. These descriptive statistics suggest that our sample is unsurprisingly heterogeneous. In this study, the empirical methods are highly favourable to cope with heterogeneity issues, especially the dynamic panel threshold regression which includes GMM procedure in the estimation of coefficients. Therefore, the data is convenient to determine possible nonlinearities between trade openness and financial development.

\section{Empirical Results}

First, the following regression model is estimated:

$Y_{i t}=\mu_{i}+\alpha^{\prime} X_{i t}+\beta_{1}^{\prime} F I N A N C E_{i t} I\left(F I N A N C E_{i t} \leq \lambda\right)+\beta_{2}^{\prime} F I N A N C E_{i t} I\left(F I N A N C E_{i t}>\lambda\right)+\varepsilon_{i t}$

Here, $\mu_{i}$ is the country specific fixed effect. $Y_{i t}$ denotes one of the three measures of trade openness. $X_{i t}$ is the vector of control variables that includes GDP per capita, gross fixed capital formation, government final consumption expenditures and inflation. FINANCE $E_{i t}$ is a variable that is dependent to regimes and its coefficient is allowed to differ.

The estimation results of Equation (3) are presented in Table 2. Three estimations are reported: the first column represents the estimation results for TRADE/GDP, while second and 
third columns represent EX/GDP and IM/GDP respectively. First, the results indicate that there is a significant threshold value around $91 \%$. The existence of significant threshold suggests that the relationship between financial development and trade openness indicators is not monotonic, that is there are two regimes: upper and lower regime. On any of the regimes the impact of financial development is specific. Second, we find that the estimated coefficients of financial development have different signs below and above the threshold level for TRADE/GDP and EX/GDP estimations. Specifically, in the lower regimes of TRADE/GDP and EXP/GDP, the estimated coefficients of financial development are positive and statistically significant at $1 \%$ significance level. Then, the coefficients turn out to be significantly negative in the upper regimes in both TRADE/GDP and EX/GDP specifications. These results suggest that a further increase in financial development below the threshold level improves trade openness whereas the financial development that is beyond the threshold value reduces trade openness. When IM/GDP is estimated, it is seen that the link between imports and financial development is significantly positive in the lower regime but in the upper regime, there is no significant relationship. The results in column (a) and column (b) support the inverted U-shape relationship between financial development and trade openness. Once $91 \%$ level is surpassed estimated positive link disappears and turns to be negative.

Table 2

Static Panel Threshold Regression Results

\begin{tabular}{lccc}
\hline Dependent Variable & $\mathbf{( a )}$ & $\mathbf{( b )}$ & $\mathbf{( c )}$ \\
& TRADE/GDP & EX/GDP & IM/GDP \\
\hline Threshold Estimate & $91.311^{* * *}$ & $91.311^{* * *}$ & $91.311^{* *}$ \\
$95 \%$ Confidence Interval & {$[89.645-91.311]$} & {$[89.645-91.311]$} & {$[88.350-123.150]$} \\
\hline \multirow{2}{*}{ Lower regime } & $0.317 * * *$ & $0.127^{* * *}$ & $0.189^{* * *}$ \\
& $(0.055)$ & $(0.030)$ & $(0.028)$ \\
Upper regime & $-0.192^{* *}$ & $-0.145^{* * *}$ & -0.047 \\
& $(0.071)$ & $(0.039)$ & $(0.036)$ \\
\hline GDPPC & $0.007^{* * *}$ & $0.005^{* * *}$ & 0.001 \\
& $(0.0001)$ & $(0.0001)$ & $(0.0007)$ \\
GFC & $0.991^{* * *}$ & $0.351^{* * *}$ & $0.639^{* * *}$ \\
& $(0.143)$ & $(0.077)$ & $(0.072)$ \\
GOVCON & 0.007 & $-0.278^{* *}$ & $0.286^{* *}$ \\
& $(0.242)$ & $(0.132)$ & $(0.123)$ \\
INF & -0.002 & -0.001 & -0.004 \\
& $(0.004)$ & $(0.002)$ & $(0.002)$ \\
Intercept & $-63.021^{* * *}$ & $-34.886^{* * *}$ & -28.134 \\
\hline \# observations & $(9.525)$ & $(5.187)$ & $(4.852)$ \\
\hline Notes. ${ }^{*}, * *, * *$ indicate significance & 576 & 576 & 576 \\
parentheses. & & &
\end{tabular}


Table 2 also represents the coefficients of control variables. It is found that GDP per capita has a significant positive effect on trade openness except the regression for IM/GDP. This finding is consistent with the results of Gächter and Gkrintzalis (2017) and Sare (2019). As expected, the gross capital formation has positive and significant impact on all trade openness variables as argued in Hur et al. (2006) and Gächter and Gkrintzalis (2017), indicating that increase in physical capital endowment positively contributes to trade openness associated with comparative advantages. Inflation is insignificant in all specifications whereas government expenditures have a positive impact on only imports.

In pursuit of considering the dynamic nature of trade and providing evidence on compatible thresholds, a dynamic panel threshold regression that introduces a further improvement in threshold modelling is also utilized. The static regression equation (3) is transformed into dynamic panel threshold regression model by adding the lagged dependent variable. The specification of dynamic panel threshold regression as follows:

$$
\begin{aligned}
& Y_{i t}=\mu_{i}+\gamma Y_{i, t-1}+\alpha^{\prime} X_{i t}+\beta_{1}^{\prime} \operatorname{FINANCE}_{i t} I\left(F I N A N C E_{i t} \leq \lambda\right)+ \\
& \beta_{2}^{\prime} F I N A N C E_{i t} I\left(F I N A N C E_{i t}>\lambda\right)+\varepsilon_{i t}
\end{aligned}
$$

Equation (4) includes a lagged variable of dependent variable $\left(Y_{i, t-1}\right)$ that capture the dynamic nature of the trade openness. The coefficient of $Y_{i, t-1}$ reflects the persistence in the process of adjustment. The results of the dynamic panel threshold regression are shown in Table 3 and they reveal that for all trade openness indicators, the estimated threshold level is $83 \%$ and it is significant. In dynamic representation of the link between financial development and trade openness, the threshold level is relatively lower than in its static representation. Moreover, it is seen that in column (a) and (b), the effect of financial development on TRADE/GDP and EX/GDP is significantly positive in the lower regime but in the upper regime, the relation between financial development and TRADE/GDP and EX/GDP turns out to be significantly negative. The results of these two specifications confirm the results in static model and suggest a nonlinear relationship. 
Table 3

Dynamic Panel Threshold Regression Results

\begin{tabular}{|c|c|c|c|}
\hline Dependent Variable & $\begin{array}{c}\text { (a) } \\
\text { TRADE/GDP }\end{array}$ & $\begin{array}{c}\text { (b) } \\
\text { EX/GDP }\end{array}$ & $\begin{array}{c}\text { (c) } \\
\text { IM/GDP }\end{array}$ \\
\hline $\begin{array}{l}\text { Threshold estimate } \\
95 \% \text { Confidence Interval }\end{array}$ & $\begin{array}{c}83.211 \\
{[75.297-85.261]}\end{array}$ & $\begin{array}{c}83.211 \\
{[77.318-85.261]}\end{array}$ & $\begin{array}{c}83.211 \\
{[33.176-85.261]}\end{array}$ \\
\hline Upper regime & $\begin{array}{c}0.227 * * * \\
(0.078) \\
-0.027 \\
(0.038)\end{array}$ & $\begin{array}{c}0.102 * * * \\
(0.032) \\
-0.059 * * \\
(0.027)\end{array}$ & $\begin{array}{c}0.154 * * * \\
(0.045) \\
0.024 \\
(0.017)\end{array}$ \\
\hline$Y_{i, t-1}$ & $\begin{array}{c}0.686^{* * * *} \\
(0.190)\end{array}$ & $\begin{array}{l}0.481^{* * *} \\
(0.167)\end{array}$ & $\begin{array}{c}0.629 * * * \\
(0.178)\end{array}$ \\
\hline GDPPC & $\begin{array}{l}-0.002 \\
(0.001)\end{array}$ & $\begin{array}{l}0.003^{* *} \\
(0.001)\end{array}$ & $\begin{array}{l}-0.006 \\
(0.006)\end{array}$ \\
\hline GFC & $\begin{array}{c}0.606^{* * *} \\
(0.214)\end{array}$ & $\begin{array}{c}0.209 * * * \\
(0.077)\end{array}$ & $\begin{array}{c}0.474 * * * \\
(0.108)\end{array}$ \\
\hline GOVCON & $\begin{array}{c}0.100 \\
(0.099)\end{array}$ & $\begin{array}{l}-0.032 \\
(0.075)\end{array}$ & $\begin{array}{c}0.104 \\
(0.071)\end{array}$ \\
\hline INF & $\begin{array}{l}-0.001 \\
(0.001)\end{array}$ & $\begin{array}{c}-0.001 * * \\
(0.000)\end{array}$ & $\begin{array}{c}0.005 \\
(0.004)\end{array}$ \\
\hline Intercept & $\begin{array}{c}-32.240 * * * \\
(9.336)\end{array}$ & $\begin{array}{c}-20.459 * * * \\
(5.014)\end{array}$ & $\begin{array}{c}-14.891 * * * \\
(4.602)\end{array}$ \\
\hline \# observations & 576 & 576 & 576 \\
\hline
\end{tabular}

Notes. ${ }^{*}, * *, * * *$ indicate significance levels at $10 \%, 5 \%$ and $1 \%$ respectively. Standard errors are given in parentheses.

The overall evidence indicates that finance fosters trade openness in terms of total trade and exports until $83 \%$ is achieved. Beyond that threshold level, further increases in the level of financial development lead to decline in trade openness. However, in column (c), the relationship between imports and financial development follows a different pattern from the first two specifications. As reported in column (c), the lower regime shows a positive relationship between IM/GDP and financial development whereas the upper regime indicates that there is no significant impact of financial development on IM/GDP. It is important to note that the link between imports and financial development is also non-monotonic. However, the significant positive link disappears after a certain financial development level is achieved.

As reported in Table 3, the estimated coefficient of lagged dependent variable is statistically significant and positive in all estimations suggesting the high dependency of trade openness to its lagged values. Capital formation is also positively related with all trade openness indicators and has statistically significant coefficient. However, government consumption expenditure is found to be statistically insignificant in all estimations. The estimated coefficient of GDP per capita is 
significantly positive, while the coefficient of inflation is significantly negative for only exports as reported in column (b). These findings are not particularly surprising in the light of previous studies (Hur et al. 2006; Gächter and Gkrintzalis 2017) and also confirm the results of static panel threshold regression analysis in previous part.

The findings of this empirical analysis share a number of similarities and differences with number of similarities with previous research about the nonlinear link between trade and finance. Primarily, the existence of the nonlinear relationship in finance-trade nexus match well with their findings. However, the estimated threshold values in this analysis are lower than the thresholds reported by Gächter and Gkrintzalis (2017). The computational methods that are preferred are probably responsible for these differentials. It is also fundamental to note that one of the distinguishing features of this analysis is the opposite signs of estimated coefficients of financial development above and below the threshold level for TRADE/GDP and EX/GDP. Despite the fact that Gächter and Gkrintzalis (2017) indicate that the impact of financial development on trade is decreasing with increasing levels of financial development, current findings strongly assert the existence of a turning point in the relationship that leads to decline in trade after a certain threshold. This evidence reveals an inverted U-shape link between trade and finance. 5.5.

\section{Conclusion}

This paper investigates the threshold effects of financial development on trade openness. Using static and dynamic panel threshold estimation techniques based on 64 counties over the period of 1970-2014, I find significant financial development thresholds that address nonlinearities. The evidence from this study suggests that countries in which financial development surpasses the level of threshold, further increases in financial development lead to decline in trade openness. These findings add substantially to our understanding of finance-trade nexus and implicate the challenging role of a financial development. Although, a better financial system is able to provide comparative advantage to countries and promotes trade, it is possible to observe a weakening in trade openness when countries become more financially developed. The results of this study provide significant empirical support for nonlinearities in finance-trade nexus and are possibly encouraging for policy makers to develop alternative channels for trade financing. One of the issues for future work may be the examination of factors that lie behind the trade-limiting effect of financial development on trade openness. 


\section{References}

Alam, M. S., Selvanathan, E. S. \& Hossain, M. (2019). Causal relationship between apparel exports and macroeconomic factors. Applied Economics, 51(25), 2687-2702. doi: $10.1080 / 00036846.2018 .1527447$

Arcand, J. L., Berkes, E. \& Panizza, U. (2015). Too much finance?. Journal of Economic Growth, 20(2), 105-148. doi:10.1007/S10887-015-91 15-2

Arellano, M. \& Bover, O. (1995). Another look at the instrumental variable estimation of errorcomponents models. Journal of Econometrics, 68(1), 29-51. doi: 10.1016/03044076(94)01642-D

Aslam, A., Boz, E., Cerutti, E., Poplawski-Ribeiro, M., \& Topalova, P. (2018). The slowdown in global trade: a symptom of a weak recovery?. IMF Economic Review, 66(3), 440-479. doi: $10.1057 / \mathrm{s} 41308-018-0063-7$

Beck T., Kunt A. D. \& Ross, L. (2000). A new database on financial development and structure. World Bank Economic Review, 14, 597-605. Retrieved from https://www.worldbank.org/en/publication/gfdr/data/financial-structure-database

Beck, T. (2002). Financial development and international trade: Is there a link?. Journal of International Economics, 57(1), 107-131. doi: 10.1016/S0022-1996(01)00131-3

Beck, T. (2003). Financial dependence and international trade, The World Bank, WPS2609.

Beck, T., Degryse, H. \& Kneer, C. (2014). Is more finance better? Disentangling intermediation and size effects of financial systems. Journal of Financial Stability, 10, 50-64. doi: 10.1016/j.jfs.2013.03.005

Becker, B., Chen, J. \& Greenberg, D. (2012). Financial development, fixed costs, and international trade. The Review of Corporate Finance Studies, 2(1), 1-28. doi: 10.1093/rcfs/cfs005

Berman, N. \& Héricourt, J. (2008). Financial constraints and the margins of trade: Evidence from cross-country firm-level data. Journal of Development Economics, 93(2), 206-217. doi: 10.1016/j.jdeveco.2009.11.006

Berthou, A. (2007). Credit Constraints and Zero Trade Flows: The Role of Financial Development. In Empirical Investigations in International Economics, 4th Annual Conference. Retrieved from https://www.freit.org/EIIE/2007/Papers/berthou.pdf

Caner, M. \& Hansen, B. E. (2004). Instrumental variable estimation of a threshold model. Econometric Theory, 20(5), 813-843. doi: 10.1017/S026646660420501 1

Do, Q. T. \& Levchenko, A. A. (2007). Comparative advantage, demand for external finance, and financial development. Journal of Financial Economics, 86(3), 796-834. doi: 10.1016/j.jfineco.2006.11.004

Gächter, M. \& Gkrintzalis, I. (2017). The finance-trade nexus revisited: is the global trade 
slowdown also a financial story?. Economics Letters, 158, 21-25. doi: 10.1016/j.econlet.2017.05.037

Giorgioni, G. (2017). Development Finance: Challenges and Opportunities. Springer.

Hansen, B. E. (1999). Threshold effects in non-dynamic panels: estimation, testing, and inference. Journal of Econometrics, 93(2), 345-368. doi: 10.1016/S0304-4076(99)00025-1

Hur, J., Raj M. \& Riyanto, Y. E. (2006). Finance and trade: A Cross-country empirical analysis on the impact of financial development and asset tangibility on international tade. World Development, 34(10), 1728-1741. doi: 10.1016/j.worlddev.2006.02.003

Kletzer, K. \& Bardhan, P. (1987). Credit markets and patterns of international trade. Journal of Development Economics, 27(1-2), 57-70. Retrieved from https://www.econstor.eu/bitstream/10419/160443/1/cdp520.pdf

Kremer, S., Bick, A. \& Nautz, D. (2013). Inflation and growth: New evidence from a dynamic panel threshold analysis. Empirical Economics, 44(2), 861-878. doi: 10.1007/s00181-0120553-9

Manova, K. (2008). Credit constraints, equity market liberalizations and international trade. Journal of International Economics, 76(1), 33-47. doi: 10.1016/j.jinteco.2008.03.008

Manova, K., Wei, S. J. \& Zhang, Z. (2015). Firm exports and multinational activity under credit constraints. Review of Economics and Statistics, 97(3), 574-588. doi: 10.1162/REST_a_00480

Matsuyama, K. (2005). Credit market imperfections and patterns of international trade and capital flows. Journal of the European Economic Association, 3(2-3), 714-723. doi: 10.1162/jeea.2005.3.2-3.714

Sare, Y. A. (2019). Threshold effects of financial sector development on international trade in Africa. International Journal of Finance \& Economics, 1-27. doi: 10.1002/ijfe. 1802

Svaleryd, H. \& Vlachos, J. (2005). Financial markets, the pattern of industrial specialization and comparative advantage: Evidence from OECD countries. European Economic Review, 49(1), 113-144. doi: 10.1016/S0014-2921(03)00030-8

Wynne, J. (2005). Wealth as a determinant of comparative advantage. American Economic Review, 95(1), 226-254. doi: 10.1257/0002828053828626 


\section{Appendix}

\section{A1. Country Sample}

Argentina, Australia, Austria, Belgium, Bolivia, Brazil, Burundi, Chile, Colombia, Costa Rica, Cote d'Ivoire, Denmark, Dominican Republic, Ecuador, Egypt, Arab Rep., El Salvador, Fiji, Finland, France, Gabon, Germany, Ghana, Greece, Guatemala, Guyana, Honduras, Iceland, India, Ireland, Israel, Italy, Japan, Kenya, South Korea, Madagascar, Malawi, Malaysia, Malta, Mexico, Morocco, Netherlands, Norway, Pakistan, Panama, Peru, Philippines, Portugal, Rwanda, Saudi Arabia, Senegal, Singapore, South Africa, Spain, Sri Lanka, Swaziland, Sweden, Thailand,

Trinidad and Tobago, Tunisia, Turkey, United Kingdom, United States, Uruguay, Venezuela

\section{A2. Data Descriptions and Sources}

\begin{tabular}{ll}
\hline Variable & \multicolumn{1}{c}{ Description } \\
\hline TRADE/GDP & $\begin{array}{l}\text { Sum of exports and imports of goods and services as a share of GDP. Source: World } \\
\text { Bank World Development Indicators (WDI) } \\
\text { Exports of goods and services as share of GDP. Source: World Bank World Development } \\
\text { Indicators (WDI) }\end{array}$ \\
IM/GDP & $\begin{array}{l}\text { Imports of goods and services as a share of GDP. Source: World Bank World } \\
\text { Development Indicators (WDI) }\end{array}$ \\
FINANCE & $\begin{array}{l}\text { Private Credit by Deposit Money Banks and Other Financial Institutions as a share of } \\
\text { GDP, Beck et al. (2000) Financial Structure Database }\end{array}$ \\
GDPPC & $\begin{array}{l}\text { Gross domestic product per capita calculated by constant 2010 U.S. dollars } \\
\text { Gross fixed capital formation as a share of GDP. Source: World Bank World }\end{array}$ \\
Development Indicators (WDI) & $\begin{array}{l}\text { General government final consumption expenditure as a share of GDP. Source: World } \\
\text { Bank World Development Indicators (WDI) } \\
\text { Annual percentage change in consumer price index. Source: World Bank World } \\
\text { Development Indicators (WDI) }\end{array}$ \\
\hline
\end{tabular}

